\title{
DIE STIGTING EN WERKSAAMHEDE VAN DIE "NEDERLANDSCH BIJSTANDSFONDS VOOR ZUID-AFRIKA" (1900-1903)
}

\author{
Kol dr Jan Ploeger*
}

\section{INLEIDING}

Die Tweede Anglo-Boereoorlog (1899 1902) het byna drie jaar gewoed.

Die Britse militêre verliese is, afgerond, op ongeveer 7000 gesneuweldes en 20000 gewondes geskat. Die republikeinse militêre verliese word op ongeveer 4000 gesneuweldes bereken. Die aantal gewondes is onbekend, terwyl ongeveer 27000 Boere ' $n$ deel van die oorlog as krygsgevangenes in kampe in Suid-Afrika of elders deurgebring het.

Van die burgerlike bevolking was ongeveer 116000 Blankes en 115000 Swartes in kampe gevange gehou. Die konsentrasie- of burgerkampe het 27027 mans, vrouens en kinders as slagoffers geëis. Hierdie getal het ongeveer 14000 kinders ingesluit. Die kampe vir Swartes het meer as 15000 lewens geëis.

Die oorlog wat met soveel lyding en ontreddering gepaard gegaan het, het meegevoel en bewondering in die wêreld laat opvlam. Nederland het ' $n$ daadwerklike aandeel aan die hulpverlening aan die Boere gehad. Dit blyk onder meer uit Ulrich Kroll se standaardwerk "Die Internationale Buren Agitation" (Münster, 1973) en die oorlogstydse jaarverslae van die "Nederlandsch"Zuid-Afrikaansche Vereeniging" (NZAV). Tientalle komitees het hulle met die een of ander vorm van steunverlening aan die Boere besiggehou. 'n Belangrike skakel in dié verband was die "Nederlandsch Bijstandsfonds voor Zuid-Afrika" (Amsterdam. Pretoria) en die "Nederlandsche Bank- en Credietvereeniging voor ZuidAfrika" (Pretoria). Vandag is hierdie onderwerp ' $n$ vergete hoofstuk in die geskiedenis van die genoemde oorlog.
Op 12.5.1881 is die Nederlandsch ZuidAfrikaansche Vereeniging" (NZAV) in Amsterdam, Nederland gestig met die doel om onder meer die landbou. handel en nywerheid in Suid-Afrika te bevorder en om die Nederlandse samelewing oor verhoudings in ons land voor te lig. Die geestelike en kulturele betrekkings tussen Nederland en ons land, veral ten opsigte van die destydse Boererepublieke, is ' $n$ tydlank deur prof dr C.B. Spruyt (1842-1901) behartig. Hy het hom onder andere vir die oprigting van die "Studiefonds voor Zuid-Afrikaansche Studenten" (1888) en die verskaffing van boeke vir skool- en dorpsbiblioteke asook onderwysdoeleindes beywer.

Ook is Nederlandse onderwysers(-esse) uitgestuur. Verder is die "Taalfonds tot behoud en bevordering van het Hollandsch als Volkstaal in de BoerenRepublieken van Zuid-Afrika" op 19.5.1896 in Amsterdam in die lewe geroep.

Die doelstelling van die "Taalfonds" was om die Boere kultureel en ekonomies sterker aan die "Moederland" (Nederland) te bind en minder vatbaar vir Engelse invloede te probeer maak.

In Mei 1899 is die voorsitterskap van die NZAV op ' $n$ algemene vergadering aan dr G.A.A. Middelberg opgedra met J.B. Loman as penningmeester en Paul den Tex as sekretaris. Dr Middelburg was van 1846 tot 1916 die ouddirekteur van die "Nederlandsch ZuidAfrikaansche Spoorweg Maatschappij" (NZASM) in Pretoria.

Die dreigende oorlog in Suid-Afrika het die spanning in die geledere van die NZAV laat toeneem en die gevoel 
versterk om ' $n$ ernstige woord tot die Britse volk te rig. 'n Manifes met die titel "Aan het volk van Groot-Britannië" is op die bestuursvergadering van 20.7.1899 goedgekeur en die teks is in Engels, Frans en Duits vertaal en aan die Nederlandse en buitelandse pers beskikbaar gestel. Die verspreiding van hierdie oproep is deur die "Algemeen Nederlandsch Verbond" (ANV) selfs tot in die Verenigde State deurgevoer.

In Augustus 1899 het die "Nederlandsch Comit voor Transvaal" sy verskyning gemaak en in September is die oproep "Een woord tot het volk van GrootBritannië en lerland" gepubliseer en in Engels, Frans en Duits versprei. Hierdie organisasie het ook protesvergaderings in Amsterdam (25.8.1899) en Den Haag (1.9.1899) belê.

Op 16.10.1899 het die NZAV weer op die voorgrond getree deur 'n pleidooi vir die mediese versorging van gewonde burgers en ander oorlog-slagoffers te lewer. 'n Paar dae ná die uitbreek van die oorlog in Suid-Afrika is geldelike steun vir die stuur van ambulanse en medisyne na die oorlogsterrein gevra, terwyl ondersteuning vir verminktes, weduwees en wese ook beklemtoon is. In Nederland en deur Nederlandse komitees (o.m. in Parys, Londen en die VSA) is tot 12.5.1900 ongeveer $196000: 0: 0$ ingesamel en is o.m. die eerste ambulans deur die Nederlandse Rooikruis, onder leiding van dr G.W.S. Lingbeek (1860-1939), na Suid-Afrika gestuur.

Verder is met jonkheer J.A. van Kretschmar van Veen (1857-1931), oud-sekretaris van die NZAV en direkteur van die NZASM, te Pretoria, in verbinding getree met die versoek om ' $\mathrm{n}$ kommissie in die lewe te roep om beheer oor die "Nederlandsch Bijstandsfonds voor Zuid-Afrika" uit te oefen.

\section{DIE STIGTING VAN DIE "BIJSTANDSFONDS" (10.1.1900)}

Die doel van bogenoemde fonds was om, in oorleg met die regerings van die twee republieke, die geld te beheer wat by die NZAV in Nederland en in die buiteland, ingesamel is om die oorlogsnood in Suid-Afrika te help verlig.
Die kommissie in Suid-Afrika wat dié taak sou verrig, het bestaan uit:

A.D.W. Wolmarans (1857-1928), lid van die Transvaalse Uitvoerende Raad, en N.S. Malherbe, Tesourier-generaal van die ZAR, albei benoem deur die regering van die Zuid-Afrikaansche Republiek (ZAR). C.H. Wessels (1851-1924), Voorsitter van die Vrystaatse Volksraad, en die Tesourier-Generaal van die OVS is albei benoem deur die regering van die Oranje-Vrystaat (OVS). Die ander lede was: Jonkheer J.A. van Kretschmar van Veen (1857-1931). direkteur van die Nederlandsch ZuidAfrikaansche Spoorweg-Maatschappij" (NZASM): prof dr N. Mansvelt (18521933). Superintendent van Onderwys, ZAR; prof dr G.A.F. Molengraaff (18601942), Staatsgeoloog, ZAR; F.P.J. van Nikkelen Kuyper (1838-1911), Weesheer, ZAR; P.W.T. Bell, Direkteur van die Staatsdrukkery, ZAR: M.E. de Wildt, Hoofingenieur en raadgewer van die NZASM, en H.C. Jorissen (1866-1949), hoof van die "Nederlandsche Bank- en Credietvereeniging voor Zuid-Afrika" (Pretoria).

Die Nederlandse konsul-generaal in Kaapstad het geld uit dieselfde bron in Nederland (NZAV) ontvang, wat aan Boerekrygsgevangenes bestee is. Aanvanklik het die bestuur onveranderd gebly, maar as gevolg van die Britse militêre besetting van Pretoria, wat o.m. is gevolg deur deportasies van Nederlanders, het wysigings begin voorkom. Prof dr N. Mansvelt en prof G.A.F. Molengraaff is deur jonkheer $d r$ W.H. de Savornin Lohman en argitek K. van Rijsse opgevolg. Op 19.9.1900 is Wolmarans en Malherbe, wat na Europa vertrek het, deur J.S. Smit (18451904) en J.C. Minnaar (1848-1913) vervang. Op 13.10.1900 het, as gevolg van ' $n$ deportasiebevel, jonkheer Van Kretschmar van Veen na Nederland teruggekeer. Hy is as voorsitter deur jonkheer dr De Savornin Lohman opgevolg, terwyl M.P. Barendsen as bestuurslid tot die "Bijstandsfonds" toegetree het.

\section{WERKSAAMHEDE VAN DIE "BIJSTANDSFONDS"}

Die kommissie was aanvanklik voornemens om na die oorlog met sy 
werksaamhede te begin, maar namate die oorlog teen die republieke begin toeneem en armoede begin heers het, is op 14.6.1900 besluit om hulp te verleen in die vorm van rentelose voorskotte met of sonder onderpand. Dit was voorlopig nie die bedoeling om veel geld te gee nie. Met hierdie doel voor oë het die kommissie met die Pretoriase "Liefdadigheids-Genootschap" en die plaaslike Britse "Relief Committee" begin saamwerk.

Die Britse regering het veral voedsel aan behoeftiges verskaf en die kommissie het besluit om aanvullend op te tree deur klere en mediese hulp aan noodlydendes te gee. Die hulp is regstreeks verleen of geldelike bydraes is aan die genoemde liefdadigheidsgenootskap verskaf. Reëlings in dié verband is deur ' $n$ onderkommissie van die "Bijstandsfonds", bestaande uit M.E. de Wildt en P.W.T. Bell, getref. Hulle is deur W.E. Hollard (1836-1906), 'n bekende Pretoriase prokureur en voorsitter van die "Relief Committee" bygestaan om aanvrae te ondersoek en in oorleg met die liefdadigheidsgenootskap op te tree.

Verder is reisgeld beskikbaar gestel aan persone wat gedwonge of vrywillig uit die Republiek vertrek het. In die meeste gevalle het die Britse regering die oortog betaal, sodat die kommissie se uitgawes in dié verband betreklik gering was.

Ook is bydraes aan ' $\mathrm{n}$ kommissie gemaak wat krygsgevange of gewonde burgers in hospitale van versnaperinge voorsien het.

Dan is ook steun verleen aan die onderwys van kinders van behoeftige ouers wat, as gevolg van die oorlog. nie meer in staat was om skoolgeld te betaal nie.

Hierdie ondersteuning is aan skoolgaande kinders in Pretoria en Johannesburg verleen. Terwyl die beskikbare fondse vir Pretoria voldoende was, was die geldmiddeld vir Johannesburg ontoereikend. In dié verband is duidelik beklemtoon dat geldelike hulp slegs as 'n uitvloeisel van oorlogsomstandighede verleen sou word.

Van veel groter omvang was die bedrag wat aan rentelose voorskotte. veral aan amptenare van die ZuidAfrikaansche Republiek, verleen moes word. Toe die Transvaalse regering aan die begin van Junie 1900 uit Pretoria vertrek het, was die regering aan die meeste amptenare nog ' $n$ aansienlike bedrag aan agterstallige salarisse verskuldig. Om die skuld te vereffen is tjeks of papiergeld uitbetaal wat egter nie deur die Britse bewind in kontant gewissel is nie. Die "Bijstandsfonds' het, in ruil vir die vorderingsbewyse, klein voorskotte aan hulpbehoewende amptenare gegee. Nadat die Britse militêre owerheid beswaar teen hierdie soort hulpverlening geopper het, het die "Bijstandsfonds" geen verdere voorskotte op banknote of tjeks uitgegee nie."

Voorskotte ten opsigte van onroerende goedere is aan ' $n$ kommissie i.v.m. Nederlanders en oud-Nederlanders wat in geldelike moeilikheid geraak het, voorsien.

\section{VERDELING VAN DIE WERKSAAMHEDE}

Die hoofkommissie van Pretoria is, behalwe deur 'n plaaslike onderkommissie in die hoofstad, ook deur onderkommissies in Johannesburg. Maraisburg en Bloemfontein bygestaan. Waar geen onderkommissies bestaan het nie. is korrespondente aangestel.

Op 10.1.1900 is in Bloemfontein ' $n$ onderkommissie, bestaande uit $\mathrm{dr} J$. Brill (1842-1924), Van Beest van Andel, Wentink, A. Fischer (1850-1913) en J. Bisseaux in die lewe geroep. Die twee eersgenoemdes het hulle aan die onderkommissie onttrek en is op 19.9.1900 deur ' $n$ nuwe onderkommissie, bestaande uit J. Bisseux en P.J. Blignaut (1841-1909), opgevolg. Die Britse militêre owerheid het die werksaamhede van die onderkommissie bemoeilik. Slegs 'n geringe bedrag van die £1000:0:0 wat by die oprigting van die onderkommissie na Bloemfontein gestuur is, was op 31.12.1900 uitgegee.

In Johannesburg het die onderkommissie uit $W$. Th. Konijnenburg, Van Schermbeek en dr J. Wiedeman bestaan. In Desember 1900 het laasgenoemde sy ontslag geneem en is deur C.J. Hoolboom as lid opgevolg. 
In Maraisburg. Florida en aangrensende dorpe was 'n onderkommissie, bestaande uit C. Dijkstra en J. Lub (1868-1926), werksaam. In Heidelberg en Potchefstroom sou vermoedelik. binne afsienbare tyd, ook onderkommissies gestig word.

\section{GELDMIDDELE IN 1900. ONTVANGSTE EN UITGAWES}

By die aanvang van sy werksaamhede het die hoofkommissie oor £10 000:0:0 beskik, wat naderhand met \&5 000:0:0 deur die NZAV (Amsterdam) aangevul is. Dié bedrag is verder met £800:0:0 wat deur jonkheer Kretschmar van Veen van die Russiese militêre attaché, kol Gurko, ontvang is, aangevul. Die NZASM-personeel in Natal het £125:8:0 bygedra en van die Amerikaanse konsul is £100:0:0 en \$959 ontvang. Die totaal van die ontrangste het $£ 16$ 059:8:0 bedra, waarvan £10 104:13:6 uitgegee is. Die saldo op 31.12.1900 was ruim 25903.

Die uitgawes het bestaan uit die volgende bedrae:

\section{Voorskotte op onderpand \\ Reisgeld \\ Voorskotte aan kommissie vir \\ Nederlanders en \\ oud-Nederlanders \\ Bydrae aan die "Benevolent Society" \\ Administrasie \\ Klere e.d.m. \\ Bydrae vir gewondes en gevangenes \\ Bydrae vir ambulanse \\ Mediese hulp \\ Skoolgeld \\ Salaris Identiteitsafdeling}

Voorskotte sonder onderpand \&l 404:07:0

Totaal

£10 104:13:0

Bostaande uitgawes, verdeel onder die hoofkommissie en die verskillende onderkommissies, gee die volgende beeld:

Pretoria - hoofkommissie - onderkommissie Johannesburg

- onderkommissie

Maraisburg - onderkommissie Bloemfontein - onderkommissie

Totaal
$£ 600: 00: 0$

$£ 100: 00: 0$ £69:00:0 £2 105:12:0

£151:13:0

$£ 875: 00: 0$

£2 17:06:0

$£ 417: 13: 0$ £30:00:0

Die batige saldo (31.12.1900) van £5903:11:6 soos volg verdeel:
Pretoria - hoofkommissie Bloemfontein onderkommissie - onderkommissie Johannesburg - onderkommissie Maraisburg - onderkommissie

Totaal

£5 $457: 17: 3$ £78:07:3

$£ 300: 00: 0$

$£ 42: 07: 0$

£25:00:0

£5 903:11:6

Aan onderpande was in besit van die hoofkommissie (31.12.1900): £3 700:00:0 aan banknote en £l 700:00:0 aan tjeks.

Tot 31.12.1900 was die ontvangste deur die NZAV (Amsterdam), vir versagting van die gevolge van die oorlog in SuidAfrika, by benadering, £102 936:00:0, terwyl aan rente ongeveer £2 520:00:0 by dié bedrag gevoeg kon word. Die groottotaal was, by benadering, £105 457:00:0. Van dié bedrag is ongeveer £16 077:00:0 aan die "Bijstandsfonds" se hoofkommissie op Pretoria gestuur. Wat die bewilliging van geldelike bydraes aan die "Bijstandsfonds" op Pretoria ongetwyfeld bevorder het, was die stigting van ' $n$ kommissie van gemagtigdes, bestaande uit vier voormalige lede van die hoofkommissie van die "Bijstandsfonds" wat na Nederland teruggekeer het. Hulle het volgens ' $n$ vasgestelde program met die bestuur van die NZAV in Amsterdam vergader om aanvrae uit Pretoria te hanteer en daaroor te beslis. Dié nuwe werkswyse is in Mei 1901 ingevoer.

\section{DIE “BIJSTANDSFONDS” IN 1901}

In 1901 het, aldus die jaarverslag van die hoofkommissie in Pretoria, die nood in Suid-Afrika steeds vergroot. Die Britse owerheid het ' $n$ lid van die hoofbestuur, die bankbestuurder, H.C. Jorissen, verplig om Transvaal te verlaat. M.E. de Wildt het die sekretaris-penningmeesterskap oorgeneem, terwyl J.J.F. Delfos tot die bestuur toegetree het. In September 1901 het P.W.T. Bell na Europa vertrek. In sy plek is dr. H.T. Reinink (1870-1939) benoem. In November het K. van Rijsse vertrek, terwyl die voorsitter, jonkheer W.H. de Savornin Lohman, ook na Nederland teruggekeer het. 
Deurdat die oorlogsnood steeds toegeneem het, het die verstrekking van voorskotte verandering ondergaan. Die toevoer van Boeregesinne na Pretoria het steeds groter geword en onder hulle was ' $n$ groot aantal behoeftiges wat vroeër welgesteld was, maar tydelik alles of byna alles deur oorlogshandelinge verloor het. Deur was en naaiwerk kon hulle slegs gedeeltelik in hulle onderhoud voorsien. Die "Bijstandsfonds" het hierdie groep gehelp met voorskotte, maar verder ook geld, klere, kostelose mediese hulp, medisyne, reisgeld en skoolgeld aan behoeftige kinders verskaf. Reisgeld is gegee aan gesinne wat na burgerkampe (konsentrasiekampe) gestuur is.

\section{DIE VOORBEREIDINGSKOMMISSIE IN PRETORIA (1901)}

'n Belangrike kommissie, wat onder die hoofkommissie van die "Bijstandsfonds" geressorteer het, was die Voorbereidingskommissie. Dié kommissie was belas met die ondersoek van aanvrae in verband met voorskotte. Bevindings is aan die hoofkommissie gerapporteer. Aangeleenthede in verband met steunverlening aan weduwees, wese. gewondes en waarborge met betrekking tot die verlening van voorskotte en die terugbetaling daarvan na die oorlog is bespreek, terwyl al die ander aanvrae aan die Onderstandskommissie vir hantering deurgestuur is.

In April 1901 is meer as honderd gesinne ondersteun. Aanvanklik is NZASMgesinne gehelp, maar later het die spoorwegmaatskappy uit eie middele geld teen 'n matige rente beskikbaar gestel. In die loop van die volgende maande is die toneel hoofsaaklik oorheers deur behoeftige gesinne wat deur die Britse militêre bevelhebbers na burgerkampe in Transvaal en Natal vervoer is. ' $n$ Ander groep het bestaan uit persone wat na Pretoria gebring is of wat daar gewoon en in behoeftige omstandighede verkeer het. In November en Desember 1900 is voorskotte aan 106 gesinne gegee, terwyl in dieselfde maande onderskeidelik 54 en 47 weduwees, as gevolg van die oorlog, met voedsel en voorskotte gehelp is. Die aantal aanvrae het toegeneem omdat heelwat gesinne vroeër voedsel van die Britse owerheid ontvang het.
Nou het dié vorm van hulp in baie gevalle opgehou omdat hulle wat nie na die burgerkampe wou gaan nie nou op hulle self aangewese was. Verder het die huurgeld van skaars huurhuise so gestyg dat hulp in baie gevalle gebiedend was. Die voorskotte en skenkings deur die "Bijstandsfonds" het van £2:0:0 tot £10:0:0 per maand beloop.

\section{DIE ONDERSTANDSKOMMISSIE TE PRETORIA (1901)}

Die Onderstandskommissie van die "Bijstandsfonds" is in die lewe geroep om aanvrae van persone, wat deur die Voorbereidingskommissie na die Onderstandskommissie verwys was, te behandel. Dit was ook die geval met aanvrae wat regstreeks van behoeftiges ontvang is. ' $n$ Ander taak was die sorg vir kostelose mediese behandeling, die uitdeel van kledingstowwe vir klere, kouse, skoene, hoede, lakens, komberse, matrasse, sowel as garing. naalde, knope e.d.m.

Die bestuur van dié kommissie was soos volg saamgestel: W.E. Hollard (voorsitter), M.E. de Wildt en P.W.T. Bell. Later het M.E. de Wildt uit die bestuur getree en is hy deur K. van Rijsse vervang. M.P. Barendsen is aan die bestuur toegevoeg.

Die kommissie kon gebruik maak van die indeling van Pretoria in 14 wyke en die diensdoende wykdames van die Liefdadigheidsgenootskap. Hulle kon ook inligting omtrent behoeftige gesinne verstrek. Gedurende die eerste ses maande is ongeveer 1224 gesinne van klere voorsien, terwyl gedurende Junie tot September 1901, 380 gesinne klere gekry en 76 gesinne geldelike steun van 10/- tot £2:0:0 ontvang het. In die maande Oktober tot Desember 1901 is onderskeidelik klere aan 92, 94 en 116 gesinne uitgedeel en van 10/tot £2:0:0 aan 45,61 en 84 gesinne gegee. In gevalle van siekte of swakte is versterkende middels, soos melk, sago, hawermout, groente, wyn e.d.m. beskikbaar gestel. Dit was ook die geval ten opsigte van kerse en seep. Dokters Reinhard en Heath het mediese hulp verleen, terwyl (eers) mej Van Beusekom en, na haar vertrek, die (geëksamineerde) apteker Gerrit Bak- 
ker in die kommissie se diens was. Van Julie tot en met September 1901 is 1900 pasiënte besoek, terwyl 1950 in die spreekkamer(s) gehelp en 1650 voorskrifte gereed gemaak is. Van Oktober tot en met Desember 1901 was die syfers laer.

\section{DIE KAMPKOMMISSIES (1901)}

Die kampkommissie in Pretoria was soos volg saamgestel: W.E. Hollard (voorsitter), M.E. de Wildt, D.J. Sim. jonkheer dr W.H. de Savornin Lohman en J.J.F. Delfos. In Pretoria was die werksaamhede toegespits op die ruskamp en die kamp by Van der Hoven's Drift. Eersgenoemde kamp was 'n deurgangsoord vir Boerekrygsgevangenes wat later, vir verdere deursending, na Ladysmith gestuur is. Die tweede kamp was bedoel vir Boeregesinne voordat hulle na die burger- of konsentrasiekampe gestuur is.

Verder was die kampkommissie bedrywig in die volgende burger- of konsentrasiekampe waar dié benoemde persone hulle bygestaan het:

Heidelberg - J.P. Ochtman en G.J. Bongers (later vervang). Middelburg dr van Gorkom, sendeling Maré en Schutstal van Woudenberg. Volksrust ds W.F. Knobel en J.L.O. Reineke. Krugersdorp - ds G. Radloff, A. te Water, H.H. du Plessis en J. Grundling. Standerton - J.J.C. van Hasselt, J.H. Everest en ds N.H.C. de Jong Teunisse. Vereenlging - J.M. Kok en E.M. Goodwin.

Johannesburg - P. Roux en Van Rheede van Oudshoorn. Nylstroom - P. van Heerden, H.J. Geldenhuys en P.J. Steenberg. Belfast - ds A.G. du Toit, H. Pellal en J.J. Schutte. Balmoral - A. op't Hoff, J. Rijkaart en J.P. Steyn. Irene - P.J.J. Swart, D.J.E. Erasmus en J. Breedt.

Die vernaamste hulp aan kampbewoners was in die vorm van klere en versterkende middels. Soms is ook geld gegee. Aanvanklik is klere en ander benodigdhede van die firma wat kampwinkels sou open bekom. Later het dié firma onwillig of onmagtig geword om sy verpligtings na te kom. Daarna is benodigdhede hoofsaaklik uit Durban en verder van Pretoriase winkels bekom. Die eerste besending na die kampe was komberse, nl. 1500 na die kampe op Volksrust en Middelburg, 500 na die kampe op Standerton en Heidelberg, 1000 na die kamp op Potchefstroom en vir verdere verdeling na kampe in Pretoria. Ook is goedere ter waarde van byna £5000:0:0 na elf Transvaalse kampe gestuur, terwyl 'n verdere besending ter waarde van f1800:0:0 in 1901 in gereedheid gebring is.

Die kampkommisse het teen die einde van 1901 nie oor verteenwoordigers in die kampe op Potchefstroom. Barberton en Pietersburg beskik nie. In die begin is hulp aan die kamp op Johannesburg verleen. Later het geblyk dat die plaaslike Kerklike Kommissie voldoende voorsien het in die behoefte aan klere in dié kamp. In Pretoria is deurtrekkende Boerekrygsgevangenes van klerasie, hemde, skoene, onderklere, e.d.m. voorsien, terwyl ook reisgeld aan hulle gegee is. Van Junie tot Desember 1901 is ' $n$ totaal van 290 persone van klere voorsien. In die Van der Hoven's Drift-kamp is noodlydende gesinne gekleed en gevoed, terwyl versterkende middels en groente aan hulle gegee is. Vrouens in die stad het klere vir die "Bijstandsfonds" gemaak, wat aan behoeftige gesinne gegee is. Eers het die gade van die Nederlandse konsul-generaal F.J. Domela Nieuwenhuis hierdie werksaamhede georganiseer. Ná haar terugkeer na Nederland het mev (ds) H.S. Bosman dié taak, na Oktober 1901, op haar skouers geneem. Sy is deur dames van die Liefdadigheidsgenootskap bygestaan.

\section{DIE ONDERKOMMISSIE IN JOHANNESBURG (1901)}

Die lede van hierdie kommissie was W. Th. van Konijnenburg, E. van Schermbeek en C.J. Hoolboom. Eersgenoemde het vertrek en is eers deur Lorentz en later deur Schuitema opgevolg. In 1901 het albei die land verlaat. Die onderkommissie het voorskotte toegestaan, geld uitbetaal, behoeftige kinders in staat gestel om skool toe te gaan en vir kostelose mediese sorg en medisyne gesorg. In die laaste ses maande van 1901 is $86,24,40,16,16$ en 24 gesinne gehelp en 106, 108, 58, 55, 110 en 121 mediese voorskrifte 
kosteloos verstrek. Waar voldoende in die behoeftes van die burgerkampbewoners voorsien, het die onderkommissie hom op behoeftiges in die buitewyke van die Goudstad toegespits. 'n Kommissie, bestaande uit di Meiring, Grasmann en mnr C.J. Hoolboom het die taak op hom geneem. Verder is geldelike bydraes weekliks aan 400 tot 500 behoeftige gesinne gegee.

\section{DIE ONDERKOMMISSIES IN MARAISBURG, KRUGERSDORP EN HEIDELBERG (1901)}

Eersgenoemde onderkommissie is in 1901 opgehef en aanvrae is vanuit Johannesburg afgehandel. Die onderkommissie in Krugersdorp het bestaan uit C. Dijkstra en prokureur Beyers.

Dr Van der Merwe het sy dienste kosteloos aangebied en van Oktober tot Desember 1901 is onderskeidelik 204, 90 en 136 mediese voorskrifte kosteloos uitgereik.

Van 25.5.1901 tot 31.12.1901 is geld, lewensmiddels en klere kosteloos uitgedeel aan 79 vrouens en 264 kinders (waar die mans op kommando was. krygsgevange geneem is of gesneuwel het), 11 weduwees en 19 kinders, 27 huisgesinne sonder inkomste, 9 wese en 4 gewonde mans met vrouens en 18 kinders.

Die onderkommissie in Heidelberg het aanvanklik uit A. van Geusau, L.B. Evers en J.P. Ochtman bestaan. Laasgenoemde het elders vertrek en volgens die kommissieverslag was die nood in Heidelberg nie besonder groot nie.

\section{DIE ONDERKOMMISSIE IN BLOEMFONTEIN (1901)}

In die loop van 1901 is besluit dat die onderkommissie in Bloemfontein regstreeks met Amsterdam in verbinding sou tree. Van 19.4.1901 tot 1.3.1902 en van Augustus 1901 tot 3.3.1902 was die ontvangste in totaal £2828:0:0 en die uitgawes £1074:6:2. Die inkomste het o.m. uit die volgende poste bestaan:

£100:0:0 van dr H.P.N. Muller (18591940), konsul-generaal van die O.V.S. in Nederland); £50:0:0 van mej B. van
Berlekom, Middelburg (Nederland); £50:0:0 van H.J. Emous (1848-1930), Amsterdam (Nederland) en £50:0:0 van die "Vereeniging Alcmaria", Alkmaar (Nederland). Onder die uitgawes is o.m. genoem: Geldsendings aan kampbewoners te Bloemfontein, Winburg, Springfontein en Heilbron; geldsendings aan krygsgevangenes te Bellary (Indië) en die hospitaal in Bloemfontein, sowel as aan die Nederlandse verpleegsters Bakkes (Winburg) en Broers (Norvalspont) en aan noodlydende gesinne in Bloemfontein en Trompsburg. Die afrekenings tot 2.3.1902 is deur $\mathrm{dr} \mathrm{J}$. Brill (1842-1924), konsulêre agent van $\mathrm{Ne}$ derland in Bloemfontein, opgestel en onderteken.

\section{HULPVERLENING IN VERBAND MET ONDERWYS AAN BEHOEFTIGE KINDERS (1901)}

Hierdie hulpverlening was beperk tot vyf skole in Pretoria en eers sewe en daarna ses skole in Johannesburg. Ongeveer drie-kwart van die leerlinge het, deur bemiddeling van die "Bijstandsfonds", kosteloos onderwys in 1901 ontvang. In Pretoria het skole in die tweede helfte van die jaar die volgende totale aantal leerlinge getel: 800 (Julie), 826 (Augustus), 676 (September), 668 (Oktober, 645 (November) en 620 (Desember). Ten opsigte van Johannesburg is die volgende gegewens in verband met die totale leerlingetal verstrek: 775 (Julie), 677 (Augustus), 640 (September), 682 (Oktober), 556 (November) en 537 (Desember).

\section{DIE "BIJSTANDSFONDS" IN 1902 - ALGEMENE OPMERKINGS EN WERKSAAMHEDE}

In die laaste oorlogsjaar is die werksaamhede van die "Bijstandsfonds" grotendeels afgesluit. In die laaste oorlogstydse verslag is dank betuig aan almal wat met toewyding aan die verwesenliking van die doelstelling hulpverlening aan noodlydende oorlogslagoffers in Suid-Afrika - gearbei het. By wyse van uitsondering is die sekretaris en die penningmeester van die Pretoriase hoofkommissie, M.E. de Wildt en M.P. Barendsen, genoem. By die oprigting is die hoop gekoester dat die Fonds ' $n$ blywende Nederlandse 
stigting sou word. Die gedagte is egter nie verwesenlik nie. Die hoop is nietemin uitgespreek "dat in de gedachten der Afrikaner natie slechts plaats moge zijn voor dankbare herinnering aan hetgeen het Nederlandsch Bijstandsfonds voor Zuid-Afrika gedurende zijn driejarige bestaan voor haar heeft kunnen doen".

In 1902 was die hoofbestuur op Pretoria soos volg saamgestel: F.P.J. van Nikkelen Kuyper (voorsitter), M.E. de Wildt (sekretaris), M.P. Barendsen (penningmeester), J.S. Smit, J.C. Minnaar, J.J.F. Delfos, dr H.T. Reinink, John Rissik en J.J. Enschede (vanaf Maart 1902).

Die werksaamhede is, tot die vredesluiting, op dieselfde grondslag as vroeer voortgesit. Aandag is veral gewy aan die steun aan behoeftige vrouens en kinders wat sonder manlike hulp moes klaarkom. Die sorg vir weduwees, wese en gewondes, sowel as vir boeregesinne sonder mans, was steeds dringend.

In die loop van 1902 het die aantal hulpbehoewendes verminder omdat die lewensomstandighede in die burger- of konsentrasiekampe draagliker begin word het. Huishure in die dorpe het skrikwekkend begin styg en hierdie twee faktore het die vraag om na die kampe gebring te word, laat toeneem. Aan gesinne wat na kampe gegaan het, is dikwels reisgeld gegee. Verder is armoede verlig deur die verskaffing van klerasie. geldelike bedraes of voorskotte, kostelose mediese hulp en medisyne en deur kostelose onderwys aan behoeftige kinders te laat gee. Ook kan o.m. vermeld word dat in April 1902 van die "Actions Comité der Burensammlung für Wittwen und Waisen", van Zürich (Switserland) 'n skenking van ruim $£ 470: 0: 0$ ontvang is om onder weduwees en wese in kampe verdeel te word.

Verder is die volgende bedrae deur die "Bijstandsfonds" vir weduwees en wese gestuur: Kimberley (£30:0:0), Rustenburg (£30:0:0), Krugersdorp (£250:0:0), Vryburg (£22:10:0), Balmoral (£39:0:0), Merebank (£50:0:0), Germiston (£143:0:0). Boksburg (£150:0:0), Volksrust (£60:0:0), Dullstroom (£33:0:0), Standerton (£11:0:0) en ongenoemde bedrae aan die kampe op Irene en Middelburg gestuur. Weesinrigtings in Pietersburg. Rustenburg en Potchefstroom het onderskeidelik £100:0:0, £50:0:0 en £50:0:0 ontvang.

Die Pretoriase hoofkommissie is, . in bogenoemde verband. deur verskillende onderkommissies, plaaslike kampkommissies en ander bereidwillige persone bygestaan. Laasgenoemde groep het uit die volgende persone bestaan: A. Tydeman (Boksburg), M.P. Taute (Dullstroom). P. Blignaut (Bloemfontein), A.J. Hendriks (Kimberley), mej G.S.M. Zerwick (Potchefstroom). A.J. Tapper (Heidelberg), adv Buskes (Middelburg), ds MacLachIan (Germiston), ds J. van Belkum (Rustenburg), ds M.L. Fick (Potchefstroom), A. Kuit (Volksrust), dr Enslin (Merebank) en ds W.P. Rossouw (Pietermaritzburg).

\section{DIE VOORBEREIDINGSKOMMISSIE (PRETORIA, 1902)}

Aan die begin van 1902 het die genoemde kommissie bestaan uit: F.P.J. van Nikkelen Kuyper (voorsitter), J.S. Smit, J.C. Minnaar, jonkheer W.H. de Savornin Lohman en J.J. Delfos. Later is J.J. Enschedé en M.E. de Wildt aan die kommissie toegevoeg en ten slotte is die vereiste werk deur F.P.J. van Nikkelen Kuyper, J.J. Enschedé en J.S. Smit verrig. Die kommissie het aangeleenthede met betrekking tot weduwees, wese, gewondes en huisgesinne behandel wat oor vaste goedere of waarborge beskik het. Ander aanvrae is na die Onderstandskommissie verwys, terwyl - op voordrag van die Voorbereidingskommissie - aanvrae deur die hoofkommissie hanteer is.

Die aantal weduwees wat van Januarie tot Desember 1902 gehelp is, het gedurende die genoemde maande as volg daar uitgesien:

$\begin{array}{lll}\text { Januarie } & -55 & \text { (met } 166 \text { kinders) } \\ \text { Februarie } & -53 & \text { (met } 161 \text { kinders) } \\ \text { Maart } & -54 & \text { (met } 154 \text { kinders) } \\ \text { April } & -51 & \text { (met } 167 \text { kinders) } \\ \text { Mei } & -51 & \text { (met } 175 \text { kinders) } \\ \text { Junie } & -39 & \text { (met } 105 \text { kinders) } \\ \text { Julie } & -47 & \text { (met } 129 \text { kinders) } \\ \text { Augustus } & -49 & \text { (met } 151 \text { kinders) } \\ \text { September } & -75 & \text { (met } 210 \text { kinders) } \\ \text { Oktober } & -49 & \text { (met } 160 \text { kinders) } \\ \text { November } & -47 & \text { (met } 136 \text { kinders) } \\ \text { en Desember } & -50 & \text { (met } 142 \text { kinders) }\end{array}$


Oor dieselfde tydperk was die aantal gesteunde weeskinders tussen 9 en 36 , terwyl - eweneens maandeliks - gemiddeld 4 tot 16 gewondes gehelp is. Voorskotte is verleen aan vrouens wie se mans afwesig was in Januarie 1902 97 vrouens (met 391 kinders); in Februarie - 89 vrouens (met 281 kinders); in Maart - 8 vrouens (met 318 kinders); in Aprjl - 3 vrouens (met 10 kinders); in Mei - 4 vrouens (met 29 kinders); in Junie 17 vrouens (met 10 kinders); in Julie - 22 vrouens (met 79 kinders); in Augustus 13 vrouens (met 53 kinders); in September - 33 vrouens (met 102 kinders); in Oktober - 20 vrouens (met 66 kinders); in November - 19 vrouens (met 38 kinders) en in Desember - 8 vrouens (met 28 kinders). Deur dié hulp kon gesinne staande bly. Hierdie vorm van hulpverlening het in Maart 1903 ten einde geloop.

\section{DIE ONDERSTANDSKOMMISSIE (PRETORIA 1902)}

Die kommissie het aanvanklik uit W.E. Hollard, John Rissik, M.P Barendsen en dr H.T. Reinink bestaan. Op die vergaderings is aanvrae van die Voorbereidingskommissie en die Pretoria se Liefdadigheidsgenootskap hanteer. Ook is aandag aan die kostelose verskaffing van mediese hulp gewy. Verder is hoofsaaklik klerasie, skoene. kouse, hoede, omslagdoeke, komberse, lakens, slope, matrasse en veldbeddens, garing, naalde, knope, lint e.d.m. verskaf en geld (tot £2:0:0) uitgedeel. Van waarde was die medewerking van die reeds genoemde Pretoriase Liefdadigheidsgenootskap wat Pretoria in 14 wyke verdeel het. Een of twee dames het toesig in elke wyk gehou.

Ná die vrede is gesinne, wat uit die kampe gekom en plaas toe getrek het, van klere en beddegoed voorsien. Met die oog op hierdie besondere werksaamhede het die Onderstandskommissie en die Kampkommissie in Julie 1902 saamgesmelt. In Desember 1902 is die kommissie se werksaamhede deur die hoofkommissie oorgeneem. Dorpsbewoners is na openbare liefdadigheidsinstellings verwys. J.J. Enschedé het vanaf Desember 1902 die reeds vermelde werksaamhede en steunverlening gereël.

In 1902 is die volgende aantal gesinne gehelp:

\section{Maande Aantal gesinne}

$\begin{array}{lclll}\text { Januarie } & 107 & \text { (klere), } 101 & \text { (geld) } \\ \text { Februarie } & 104 & \text { (klere), } 69 & \text { (geld) } \\ \text { Maart } & 108 & \text { (klere), } 69 & \text { (geld) } \\ \text { April } & 99 & \text { (klere), } 4 & \text { (geld) } \\ \text { Mei } & 95 & \text { (klere), } & 5 & \text { (geld) } \\ \text { Junie } & 90 & \text { (klere), } 6 & \text { (geld) } \\ \text { Julie } & 189 & \text { (klere), } 9 & \text { (geld) } \\ \text { Augustus } & 254 & \text { (klere), } & 3 & \text { (geld) } \\ \text { September } & 170 & \text { (klere), } 1 & \text { (geld) } \\ \text { Oktober } & 249 & \text { (klere), } 5 & \text { (geld) } \\ \text { November } & 106 & \text { (klere), } 1 & \text { (geld) } \\ \text { Desember } & 125 & \text { (klere), } & \end{array}$

Hierdie hulpverlening het, in sy verskillende vorms, ' $n$ bedrag van ongeveer £5120:0:0 verteenwoordig. Danksy die steun van die Nederlandse Dameskomitee "Alcmaria", van die stad Alkmaar, was die hoofkommissie vanaf September 1902 in staat om aan ' $n$ groot aantal behoeftige gesinne lewensmiddele soos gort, rys, suiker, hawermeel, spek, konfyt, wors, kerse, besems e.d.m. te verskaf. Danksy die hulp van die "Zuid-Hollandsche Commissie voor Krijgsgevangenen" is " $n$ paar kaste met klere en lewensmiddele uitgedeel.

Dr Reinhardt het teen ' $n$ geringe vergoeding die kostelose verskaffing van die mediese diens in Pretoria waargeneem totdat die vorm van ondersteuning op 1.11.1902 opgehef is. Van Januarie tot Oktober is die volgende dienste deur bogenoemde verrig.

$\begin{array}{lccc}\text { 1902: } & \text { Spreekure } & \text { Voorskrifte } & \text { Besoeke } \\ \text { Januarie } & 420 & 300 & 286 \\ \text { Februarie } & 200 & 150 & 272 \\ \text { Maart } & 190 & 140 & 260 \\ \text { April } & 250 & 150 & 249 \\ \text { Mei } & 260 & 125 & 246 \\ \text { Junie } & 240 & 115 & 207 \\ \text { Julie } & 230 & 135 & 224 \\ \text { Augustus } & 155 & 98 & 202 \\ \text { September } & 135 & 97 & 198 \\ \text { Oktober } & 130 & 94 & 160\end{array}$

\section{DIE KAMPKOMMISSIE (PRETORIA, 1902)}

Hierdie kommissie, wat met die swaarste taak belas was, het uit W.E. Hollard, M.E. de Wildt, D.J. Sim en J.J. Delfos bestaan. Die werksaamhede het die vrouekampe, die ruskamp ("Rest Camp") 
in Pretoria en die kamp by Van der Hoven's Drift ingesluit. In die ruskamp het Boerekrygsgevangenes tydelik vertoef voordat hulle na hul ballingskapoorde vervoer is. In laasgenoemde kamp is Boeregesinne tydelik gehuisves voordat hulle na die burger- of konsentrasiekampe vervoer is. Die moeilikhede waarmee die kommissie te kampe gehad het, was om goedere na Pretoria vervoer te kry, die versending van voorrade na kampe en om persone te vind wat die klere, lewensmiddele, versterkende middels en soms geld in die kampe wou uitdeel. Die benodigde goedere is gedeeltelik in Pretoria aangekoop of uit Durban bekom, terwyl ook bestellings in Nederland geplaas is.

In 1902 is die kampkommissie (Pretoria) deur die volgende persone bygestaan: Heidelberg: R. von Geusau, P.J. Derwig, W. Bezuidenhout en P.G. Groesbeek. Standerton: Ds N.H.C. de Jongh Teunisse en J.H. Everest. Irene: D.J E. Erasmus, P.J.J. Zwarts en J. Breedt. Krugersdorp: Ds Gustav Radloff, D. du Plessis, A.B.B. te Water en J.D. Grundling. Balmoral: A. op '† Hof. J P. Steyn en J. Rykaard. Belfast: Ds A.G. du Toit, J.J. Schutte en S.P. Malan. Middelburg: Dr Van Gorkom, sendeling Maré en D. Schutstal van Woudenberg. Volksrust: Ds W.F Knobel en J.I.O. Reyneke. Vereeniging: E.M. Goodwin en J.M. Kok. Johannesburg: P. Roux, Van Rheede van Oudtshoorn. Nylstroom: P. van Heerden, P.J. Steenberg en H.J. Geldenhuys. Potchefstroom: Ds A. Murray, mev Murray en mev Maury.

Benewens die lede van die plaaslike kommissies het ook die volgende persone die kampkommissie bygestaan: Dullstroom en omgewing - P.A. Louw; Lydenburg en omgewing - D.J. Schoeman; Ermelo en omgewing - J.A. Smuts; Heilbron en omgewing - mev J.G. Luyt; Pietersburg en omgewing - T. Kleinenberg; Rustenburg en omgewing - ds D. Postma.

Verder is, ná die vrede, boeregesinne gehelp wat gedurende die oorlog in die veld rondgeswerf het. Die kamp by Van der Hoven's Drift is in Februarie 1902 gesluit en in Januarie 1902 is ongeveer 300 stuks klerasie en skoene. komberse, kouse, lakens, beddens, medisyne, lewensmiddels en groente onder die inwoners verdeel. In die "Rest Camp" kon die kommissie geen toegang verkry nie, maar die dames Malan en Schabort is toegelaat om klere, skoene, hemde, sokkies, hoede, kruisbande en onderklere aan die krygsgevangenes te gee. Verder is tussen Januarie en Mei 1902 van 90 tot 169 persone volledig uitgerus. Na die vrede is die "Rest Camp" gesluit. Goedere ter waarde van ongeveer £1620:0:0 is in die kamp uitgedeel. Ook is goedere na Heilbron ( $£ 60: 0: 0$ ), Dullstroom (£160:0:0), Pietersburg (£325:0:0), Lydenburg (£240:0:0), Carolina (£160:0:0), Ermelo (£160:0:0), Middelburg (£5:0:0), Volksrust (£505:0:0), Standerton (£405:0:0), Heidelberg ( $£ 305: 0: 0)$, Irene ( $206: 0: 0)$, Balmoral ( $£ 200: 0: 0$ ), Potchefstroom ( $5565: 0: 0$ ), Rustenburg (£80:0:0), Vereeniging (£200:0:0) en Krugersdorp (£750:9:0) gestuur om kampbewoners en rondswerwende boeregesinne te help.

\section{DIE ONDERKOMMISSIE IN JOHANNESBURG (1902)}

Die onderkommissie het aanvanklik uit E.V. Schermbeek en C.J. Hoolboom bestaan. In April 1902 is eersgenoemde deur adv Beyers opgevolg. Hulle het voorskotte verstrek en behoeftiges geldelik gehelp met die betaling van skoolgeld en kosteloos mediese behandeling en medisyne verskaf. Die werksaamhede is in Desember 1902 beëindig. Gedurende die eerste vier maande van die jaar is gemiddeld 550 tot 650 persone geldelik gehelp. Die mediese behandeling is aan dr Pirow en later aan dr Dedlow toevertrou. Van Januarie tot einde November 1902 is van 100 to 150 mediese voorskrifte uitgereik.

\section{DIE ONDERKOMMISSIES IN KRUGERSDORP EN HEIDELBERG (1902)}

Die Onderkommissie in Krugersdorp het onder leiding van C. Dijkstra en adv Beyers sy werksaamhede tot die einde van November voortgesit. Daar is voorskotte, gifte, lewensmiddele, kostelose mediese hulp en medisyne sowel as skoolgeld verskaf. Die aantal voorskotte en maandelikse gifte het van Januarie tot Maart 1902 tussen 109 en 130 bedra en daarna aansienlik verminder. Dr Van der Merwe het tot die einde van 1902 die geneeskundige 
werksaamhede verrig. Maandeliks is tussen 36 en 135 kostelose voorskrifte uitgereik.

In Heidelberg het die Onderkommissie uit A. von Geusau, P.J. Derwig, W. Bezuidenhout en P.G. Groesbeek bestaan. Weldra het ewenwel geblyk dat daar geen behoefte aan spesiale voorsienings bestaan nie. Van Januarie tot April 1902 is tussen 4 en 7 gesinne geldelik bygestaan.

\section{VERSTREKKING VAN KOSTELOSE ONDERWYS AAN KINDERS VAN BEHOEFTIGE OUERS (1902)}

Soos in 1901 is behoeftige ouers, wat hul kinders Hollandse onderrig wou laat geniet, geldelik gesteun. In totaal is aan hierdie werk in 1902 ongeveer £1730:0:0 in Pretoria, Johannesburg en Krugersdorp bestee. Op 31.12.1902 het die Kommissie sy werksaamhede gestaak omdat beide 'n kommissie ter behartiging van die Hollandse onderwys en die Britse regering die onderwysvraagstukke aangepak het. Verder is ' $n$ aantal gevalle na die "Generale Boeren-hulpfonds" of na diakonieë van kerkgenootskappe verwys.

Ten spyte daarvan dat daar op die plase baie gebrek gely is, moes die kommissie sy werksaamhede staak en die hulpverlening aan ander oorlaat. Sekretaris M.E. de Wildt het ap 28.3.1903 sy verslag met die volgende gedagtes afgesluit:

"Waren wij niet in staat om in een algemeenen nood te voorzien, wij gevoelen ons gelukkig in het bewustzijn van wat wij deden en konde doen"

\section{DIE "BIJSTANDSFONDS" TE BLOEMFONTEIN (1902)}

Die kommissie in Bloemfontein het, in teenstelling met die Pretoriase hoofkommissie, die meeste beskikbare geld tot na die oorlog bewaar. Toe die vrede gesluit is, was daar nog ' $n$ belangrike (ongenoemde) saldo aangewend. Later het die hoofkommissie nog £2000:0 bygevoeg. In November 1902 is aan 110 weduwees elkeen ' $n$ bedrag van £10:0:0 betaal. Ondersteuning is aan ongeveer 300 weduwees van gesneuwelde burgers en aan on- geveer 300 weduwees van burgers wat op kommando of in krygsgevangeskap heengegaan het, gelewer. Later is nog £4000:0:0 a an die kommissie oorgedra.

\section{DIE "BIJSTANDSFONDS" IN 1902 EN 1903}

Ofskoon die werksaamhede van die "Bijstandsfonds" in Pretoria in 1902 grotendeels afgehandel was, is die verwagting dat die groot nood en ellende in 1903 tot die verlede sou behoort, ongelukkig nie bewaarheid nie. Daarom is die werksaamhede in 1903 op ' $n$ beskeie wyse voortgesit. In Pretoria het die bestuur uit P.J. van Nikkelen Kuyper (voorsitter) en dr H T. Reinink (sekretaris), M.P. Barendsen (penningmeester) met M.E. de Wildt, J.J. Enschedè, J.S. Smit, J.C. Minnaar, J.J.F. Delfos en $\mathrm{J}$. Rissik as lede bestaan. Daar was aan die einde van 1902 nog ' $n$ groot voorraad goedere, wat deur hulp van die "Christelijk Nationaal Boeren Comitè" en die afdeling Den Haag van die "Nederlandsch Zuid-Afrikaansche Vereeniging" (NZAV) verder vergroot is. Die voorrade is onder die verarmde bevolking verdeel en goedere is aan behoeftiges op Dullstroom (£140:0:0), Frederikstad (£80:0:0), Krugersdorp (£70:0:0), Ermelo (£100:0:0), Potgietersrus ( $£ 5: 0: 0)$, Carolina ( $£ 80: 0: 0)$, Rustenburg (£90:0:0) en aan die weeshuise op Langlaagte en Pretoria oorgedra. Gedurende 1903 is die volgende aantal gesinne in Pretoria van klerasie voorsien:

$\begin{array}{lcl}\text { Maande } & \text { Gesinne } & \begin{array}{c}\text { Waarde van } \\ \text { klere }\end{array} \\ \text { Januarie } & 158 & £ 394: 02: 10 \\ \text { Februarie } & 75 & £ 178: 16: 7 \\ \text { Maart } & 41 & £ 101: 03: 3 \\ \text { April } & 25 & £ 47: 17: 8 \\ \text { Mei } & 52 & £ 117: 06: 7 \\ \text { Junie } & 42 & £ 121: 13: 0\end{array}$

In Augustus 1903 was die voorraad uitgeput. Verder is klerasie vir vrouens en kinders, flanel, linne, voering, skoene kouse, garing, ens, kosteloos versprei. Aan vyf verminkte burgers is kunsbene verskaf aan die "Transvaal Vrouwen Fonds" is 'n bedrag oorgedra. Die weeshuis op Witsieshoek het £50:0:0, die "Emily Hobhouse Fonds" £50:0:0 en weduwees en wese op Pretoria £40:0:0 ontvang. 
Behoeftige Nederlanders en oud-Nederlanders is met voorskotte (£145:0:0) en gifte ( $£ 489: 16: 0)$ gehelp. Ook is die kommissie vir "Christelijk Nationaal Onderwijs" geldelik ondersteun. Teen die einde van 1903 was die beskikbare fondse uitgeput. Die "Bijstandsfonds" is nie gelikwideer nie omdat baie voorskotte nog nie terugbetaal is nie. 'n Ernstige poging in verband met terugbetaling was, aldus dr Reinink in Februarie 1904, met die oog op die heersende ongunstige toestande nie wenslik nie.

In Bloemfontein, in 1903, het die plaaslike kommissie gerapporteer dat £6000:0:0 van die Oorlogsfonds en £1200:0:0 deur bemiddeling van $\mathrm{dr} \mathrm{J}$. Brill ontvang is. Verder was daar aan die begin van 1903 nog ' $n$ saldo van £650:0:0. Van die genoemde bedrae is in die loop van die jaar £100:0:0 tot $£ 150: 0: 0$ a an komitees op Boshof, Philippolis, Bethulie, Reitz, Bultfontein, Dewetsdorp, Bethlehem, Petrusburg, Vrede, Senekal, Jacobsdal, Vredefort, Ladybrand, Edenburg, Smithfield, Frankfort, Kroonstad, Brandfort, Parys, Lindley, Ventersburg, Hoopstad en Heilbron gestuur. Ook is aan die weesinrigting van H.J. Poutsma (1866-1933) te Witsieshoek, distrik Harrismith, £500:0:0 beskikbaar gestel. Aan die begin van 1904 het die Bloemfonteinse Kommissie nog oor ruim f2 200:0:0 beskik.

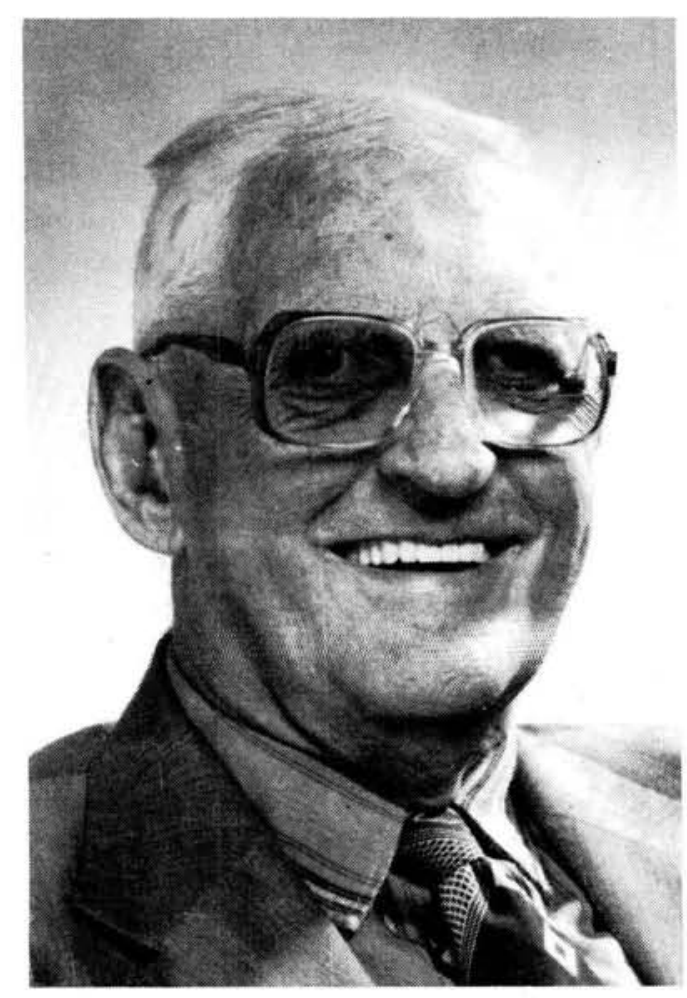

\section{DIE VERDERE LOTGEVALLE VAN DIE "NEDERLANDSCH BIJSTANDSFOND VOOR ZUID-AFRIKA" (1904-1910)}

Die skrywer beskik nie oor jaarverslae van die NZAV ná 1903 nie, maar kan uit dokumente in sy besit aflei dat dr. H.T. Reinink in 1905 nog die belange van die "Bijstandsfonds" in Pretoria behartig het.

Volgens 'n gedrukte kennisgewing van September 1910 is die "Bijstandsfonds", aldus die hoofkommissie in Pretoria (F.P.J. van Nikkelen Kuyper, J.J. Enschedè), gelikwideer. Die hoofkommissie te Pretoria het opdrag van Amsterdam ontvang om uitstaande voorskotte by invordering aan liefdadigheids instellings in Suid-Afrika te oorhandig. Een van die instellings was die Ondersteuningsfonds van die "Nederlandsche Vereeniging" (Pretoria).

\section{BRONNE}

Die "Verslag van het hoofd bestuur der Nederlandsch Zuid-Afrikaansche Vereeniging" (Amsterdam, s.j.) oor die verenigings in die jare 1899-1903 is met vrug geraadpleeg asook ander bronne waarin in voetnotas verwys is. Die Voetnotas is egter in hierdie uitgawe van Militaria weggelaat.

Vir verdere besonderhede oor die lotgevalle van die burgerlike bevolking raadpleeg o.m: J. Ploeger Die lotgevalle van die burgerlike bevolking gedurende die Anglo-Boereoorlog. 1899- 1902. (Pretoria. Staatsargiefdiens 1990). dele 1-5. pp 1883. Die uitgawe van die volledige reeks (11 dele) word voortgesit.

\footnotetext{
*Met hierdie bydrae neem Kol dr Jan Ploeger, eerste redakteur en jarelange medewerker aan "Militaria", in sy tagtigste lewensjaar afskeid van 'n publikasie wat hom, oor 'n groot aantal jare, na aan die hart gelê het. Vanaf 1969 het hy altesame 46 artikels vir Militaria geskryf.
} 